\title{
Globulin Protein Measurement
}

National Cancer Institute

\section{Source}

National Cancer Institute. Globulin Protein Measurement. NCI Thesaurus. Code C74738.

The determination of the amount of globulin protein present in a sample. 